\title{
BMJ Open Retrospective cohort study of usage patterns of epidural injections for spinal pain in the US fee-for-service Medicare population from 2000 to 2014
}

\author{
Laxmaiah Manchikanti, ${ }^{1,2}$ Vidyasagar Pampati, ${ }^{1}$ Joshua A Hirsch ${ }^{3,4}$
}

To cite: Manchikanti L, Pampati V, Hirsch JA. Retrospective cohort study of usage patterns of epidural injections for spinal pain in the US fee-for-service Medicare population from 2000 to 2014. BMJ Open 2016;6:e13042.

doi:10.1136/bmjopen-2016013042

- Prepublication history and additional material is available. To view please visit the journal (http://dx.doi.org/ 10.1136/bmjopen-2016013042).

Received 15 June 2016 Revised 28 October 2016 Accepted 10 November 2016

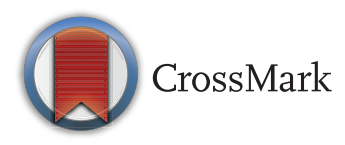

${ }^{1}$ Pain Management Center of Paducah, Paducah, Kentucky, USA

${ }^{2}$ Department of

Anesthesiology and

Perioperative Medicine,

University of Louisville,

Louisville, Kentucky, USA

${ }^{3}$ Massachusetts General

Hospital, Boston,

Massachusetts, USA

${ }^{4}$ Harvard Medical School,

Boston, Massachusetts, USA

Correspondence to Dr Laxmaiah Manchikanti; drlm@thepainmd.com

\section{ABSTRACT}

Objective: To assess the usage patterns of epidural injections for chronic spinal pain in the fee-for-service (FFS) Medicare population from 2000 to 2014 in the USA.

Design: A retrospective cohort.

Methods: The descriptive analysis of the administrative database from Centers for Medicare and Medicaid

Services (CMS) Physician/Supplier Procedure Summary (PSPS) master data from 2000 to 2014 was performed. The guidance from Strengthening the Reporting of Observational studies in Epidemiology (STROBE) was applied. Analysis included multiple variables based on the procedures, specialties and geography.

Results: Overall epidural injections increased $99 \%$ per 100000 Medicare beneficiaries with an annual increase of $5 \%$ from 2000 to 2014. Lumbar interlaminar and caudal epidural injections constituted $36.2 \%$ of all epidural injections, with an overall decrease of $2 \%$ and an annual decrease of $0.2 \%$ per 100000 Medicare beneficiaries. However, lumbosacral transforaminal epidural injections increased $609 \%$ with an annual increase of $15 \%$ from 2000 to 2014 per 100000 Medicare population.

Conclusions: Usage of epidural injections increased from 2000 to 2014, with a decline thereafter. However, an escalating growth has been seen for lumbosacral transforaminal epidural injections despite numerous reports of complications and regulations to curb the usage of transforaminal epidural injections.

\section{INTRODUCTION}

The reports of neurological complications from epidural injections have taken centre stage in the $\mathrm{USA}^{\mathrm{I}-7}$ and in other parts of the world over the years. ${ }^{8}$ Even though the basis for such alarm and subsequent regulatory atmosphere has been criticised, ${ }^{4-7}$ the explosive increase of numerous modalities to manage spinal pain including epidural injections and the economic impact have provided ammunition for such an atmosphere. ${ }^{9-18}$ Reports from the US Burden of Disease

\section{Strengths and limitations of this study}

- This assessment of usage patterns of epidural injections has been conducted to describe the characteristics of all types of epidural injections in managing chronic spinal pain in the fee-for-service (FFS) Medicare population in the USA from 2000 to 2014.

- The strengths of this assessment include use of $100 \%$ FFS Medicare population including those above and below 65 years of age.

- One of the limitations is that the study is restricted to only the Medicare population and patients with Medicare Advantage plans have not been included which constitute between 20\% and $30 \%$ of the population.

- Additionally, while these results can be generalised to a great extent, caution must be exercised since in other population groups the usage might be materially different.

Collaborators ${ }^{19}$ and from other parts of the world ${ }^{2021}$ have shown spinal pain occupying three of the five top categories of disability. In addition, the prevalence of chronic impairing low back pain has increased in one report $162 \%$ from 1992 to 2006, increasing from $3.9 \%$ to $10.2 \% .^{22}$ Further, multiple assessments also have shown the chronicity of spinal pain long after its onset. ${ }^{23} 24$ The evidence of increasing burden of disease and disability across the globe coupled with increasing numbers of treatments have created an unacceptable situation with economic, social and healthcare impact. Further complicating this circumstance is the widely debated issues of efficacy of these interventions. $^{24-40}$

The statistics show that epidural injections, including percutaneous adhesiolysis procedures, are the most commonly performed procedures in managing spinal pain among interventional techniques, varying from $58.6 \%$ in 2000 to $45.2 \%$ in 2014 of all 
interventional techniques. ${ }^{15}$ The usage of epidural procedures, excluding percutaneous adhesiolysis, showed an overall increase of $165 \%$ or $96 \%$ per 100000 fee-for-service (FFS) Medicare beneficiaries with an annual increase of $7.2 \%$ or $4.9 \%$ from 2000 to $2014^{15}$ showing a slight decrease compared to 2000 to 2013, from a rate of $105.6 \%$ to an annual increase of $5.7 \%$. Interlaminar epidural injections have increased at a slower pace. Among the epidural injections, continuous epidural injections with catheterisation and neurolytic epidural procedures have not been used in managing chronic spinal pain. Manchikanti et al, ${ }^{11-14}$ in assessing Medicare FFS population in the USA from 2000 to 2013, showed an increase of $119 \%$ for cervical and thoracic interlaminar epidural injections and $11 \%$ for lumbosacral interlaminar and caudal epidural injections per 100000 Medicare population with an annual increase of $6.2 \%$ or $0.8 \%$, respectively. Contrasting these milder increases, they determined an explosive increase of $577 \%$ for lumbosacral transforaminal epidural injections and an $84 \%$ increase of cervical and thoracic transforaminal epidural injections per 100000 Medicare population with an annual increase of $15.8 \%$ and $4.8 \%$, respectively, during the same period. ${ }^{11} 1214$ Thus, the use of epidural injections has risen dramatically, despite discordant opinions of their effectiveness and their association with rare, but catastrophic complications. ${ }^{24-44}$

This study is undertaken with an aim of assessing the usage patterns and patterns of use of epidural injections in Medicare FFS population in the USA with the analysis of data from 2000 to 2014.

\section{METHODS}

Approval by the Institutional Review Board (IRB) was not sought for this assessment as all analysis encompassed public use files (PUF) or non-identifiable data, which is non-attributable and non-confidential, available through the Centers for Medicare and Medicaid Services (CMS) database. ${ }^{45}$ The study was performed using Strengthening the Reporting of Observational studies in Epidemiology (STROBE) guidance. ${ }^{46}$

\section{Study design}

The study was designed to assess usage patterns of epidural injections, excluding continuous epidurals and neurolytic procedures, which constitute a small proportion used for chronic management, in the FFS Medicare population in the USA from 2000 to 2014.

\section{Setting}

National database of specialty usage data files from CMS, USA, FFS Medicare. ${ }^{45}$

\section{Participants}

Participants included the FFS Medicare recipients from 2000 to 2014.
For analysis, the current procedure codes for epidural injections were used. The CPT codes used included epidural codes CPT 62310, 62311 and transforaminal epidural codes CPT 64479, 64480, 64483 and 64484. These codes were identified for years 2000 to 2014. Subsequently, usage data were assessed based on the place of service, either the facility which included ambulatory surgery centres and hospital outpatient departments (HOPDs), or a non-facility setting-the office. The data are calculated for overall services for each technique, and the rate of services for 100000 Medicare beneficiaries, and also based on the specialty.

\section{Variables}

Multiple characteristics are assessed in this evaluation of the Medicare population and increase in the Medicare population from 2000 to 2014, usage of epidural procedures in the cervical, thoracic, lumbar and sacral spine. Additional characteristics assessed included various specialty designations and the settings in which the procedures were performed.

The description of various specialties was as follows: multiple specialties representing interventional pain physicians including interventional pain management -09 , pain medicine -72 , anaesthesiology -05 , physical medicine and rehabilitation -25 , neurology -13 , psychiatry -26 were described as interventional pain management. Surgical specialties included orthopaedic surgery -20 , general surgery -17 and neurosurgery -14 . Radiologic specialties included diagnostic radiology -30 and -94 interventional radiology. All other physicians were grouped into a separate group (general physicians), and all other non-physician providers were considered as other providers.

\section{Data sources}

The data were obtained from the CMS physician supplier procedure summary master data from 2000 through 2014. ${ }^{45}$ These data provide all FFS Medicare participants below the age of 65 and above the age of 65 receiving epidural procedures.

\section{Measures}

Allowed services were calculated from services submitted minus services denied and services with zero payments.

Allowed services were assessed for each procedure, and rates were calculated based on Medicare beneficiaries for the corresponding year and are reported as procedures per 100000 Medicare beneficiaries.

\section{Bias}

The study was conducted with the internal resources of the primary author's practice without any external funding, either from industry or elsewhere. The data were purchased from CMS by the American Society of Interventional Pain Physicians (ASIPP). CMS's 100\% data set consists of usage by CPT code with modifier usage (as an additional procedure or bilateral procedure), specialty codes, place of service, Medicare carrier 
number, total services and charges submitted, allowed and denied, and amount paid.

\section{Study size}

The study size is large with inclusion of all patients under Medicare FFS undergoing epidural procedures for spinal pain from 2000 to 2014.

\section{Data compilation}

The data were compiled using Microsoft Access 2003 and Microsoft Excel 2003 (Microsoft, Redmond, Washington, USA).

\section{RESULTS}

\section{Participants}

Participants included the FFS Medicare recipients from 2000 to 2014.

\section{Descriptive data}

Table 1 illustrates the characteristics of Medicare beneficiaries as well as the epidural injections provided to them. Medicare beneficiaries increased 35\% from 2000 to 2014 compared to an increase of $99 \%$ in the rate (per 100000 Medicare beneficiaries) of epidural injections with an annual increase of $5 \%$ compared to a $2.2 \%$ annual increase in the number of Medicare beneficiaries which is 2.6 times the increase of the population rate.

\section{Usage characteristics}

Table 2 and figure 1 illustrate the usage characteristics of epidural injections in the Medicare population from 2000 to 2014. Overall epidural injections increased 99\% per 100000 Medicare beneficiaries with an annual increase of $5 \%$. However, lumbosacral interlaminar and caudal epidural injections (CPT 62311) decreased 2\% per 100000 Medicare beneficiaries with a $0.2 \%$ annual decrease compared to an increase of $104 \%$ per 100000 beneficiaries and a 5.2\% annual increase for cervical/ thoracic interlaminar epidural injections (CPT 62310). In contrast, lumbosacral transforaminal epidural injections (CPT 64483 and 64484) increased 609\% per 100000 population with an annual increase of $15 \%$ and cervical/thoracic transforaminal epidural injections (CPT 64479 and 64480) increased 93\% with an annual increase of $4.8 \%$. Thus, all the decrease in usage of interlaminar epidural injections were compensated by increases of transforaminal epidural injections in the lumbar spine. In addition, cervical and thoracic transforaminal epidural injections have been decreasing from 2011 to 2013 but have shown an increase in 2014. Using the number of patient episodes providing the services, lumbar/sacral interlaminar or caudal epidural injections (CPT 62311) decreased at a rate of $-2 \%$ from 2000 to 2014, whereas the rate of usage in 2014 was 815858 services with 1525 per 100000 Medicare FFS population with a decrease of $12.2 \%$ from the previous year and the decreases observed from 2006 through 2014. In addition, the number of patient episodes with transforaminal epidural injections (CPT 64483) were slightly less with 763793 services with 1428 per 100000 Medicare population, with an increase of $15 \%$ from 2000 to 2014, with decreases observed in 2 years with $4.0 \%$ decrease in 2012 and $5.1 \%$ in 2013 with an increase of $4.7 \%$ in 2014. In 2000, 1560 patients per 100000 Medicare population received lumbar and caudal epidural injections, whereas 214 received lumbar transforaminal epidural injections. These numbers decreased for interlaminar epidural injections from 1560 to 1525 , whereas lumbar transforaminal epidural injections increased from 214 to 1428 per 100000 Medicare population.

As shown in figure 2, the proportion of epidural injections of all interventional techniques performed reduced $57 \%$ to $45 \%$ from 2000 to 2014 .

\section{Specialty characteristics}

Online supplementary appendices 1 and 2 illustrate the usage of epidural injections by various specialties. In the group of interventional pain management, including anaesthesiology, interventional pain management, pain medicine, physical medicine and rehabilitation, neurology and psychiatry, the rate of increase was $113 \%$ per 100000 Medicare beneficiaries with an overall increase of $99 \%$ from 2000 to 2014. However, among these groups, physical medicine and rehabilitation showed an overall increase of $672 \%$ and $472 \%$ per 100000 Medicare beneficiaries. Radiology, consisting of interventional radiology and diagnostic radiology, also showed an increasing rate of $167 \%$ per 100000 Medicare beneficiaries from 2000 to 2014. Surgical specialties, including neurosurgery, orthopaedic surgery and general surgery, showed an increase of 58\% from 2000 to 2014.

\section{Site of service characteristics}

Epidural injections are provided in multiple settings including HOPDs, ambulatory surgical centres (ASCs) and in physician's offices (in-office). There has been a significant shift over the years in epidural injections based on the location of the procedure's performance. In 2002, HOPD services constituted $54.3 \%$, with ASCs providing $19.9 \%$ of the service, and in-office providing 25.8\%. By 2014, the HOPD share decreased to $29.4 \%$, the ASC share increased to $27.7 \%$ and the in-office share dramatically increased to $42.9 \%$ as shown in online supplementary appendices 3 and 4 .

\section{Main results}

- Epidural injections increased $99 \%$ per 100000 Medicare beneficiaries with an annual increase of $5 \%$ in FFS Medicare beneficiaries from 2000 to 2014. Lumbar interlaminar and caudal epidural injections constituted $36.2 \%$ of all epidural injections, with an overall decrease of $2 \%$ and an annual decrease of $0.2 \%$ per 100000 Medicare beneficiaries.

- Lumbosacral transforaminal epidural injections increased $609 \%$ with an annual increase of $15 \%$ from 2000 to 2014 per 100000 Medicare population. 
Table 1 Characteristics of Medicare beneficiaries and epidural procedures excluding percutaneous adhesiolysis, continuous epidurals and neurolytic epidurals.

\begin{tabular}{|c|c|c|c|c|c|c|c|c|c|c|c|}
\hline & \multicolumn{3}{|l|}{ US population } & \multicolumn{4}{|c|}{ Medicare beneficiaries } & \multicolumn{4}{|c|}{ Epidural services* } \\
\hline & \multirow[b]{2}{*}{$\begin{array}{l}\text { Total population } \\
(, 000)\end{array}$} & \multicolumn{2}{|c|}{$\geq 65$ years $(, 000)$} & \multirow[b]{2}{*}{$\begin{array}{l}\text { Number } \\
(, 000)\end{array}$} & \multirow[b]{2}{*}{$\begin{array}{l}\text { Per cent to US } \\
\text { population }\end{array}$} & \multirow[b]{2}{*}{$\begin{array}{l}\geq 65 \text { years } \\
(, 000)(\%)\end{array}$} & \multirow[b]{2}{*}{$\begin{array}{l}<65 \text { years } \\
(, 000) \%\end{array}$} & \multirow[b]{2}{*}{ Services* } & \multirow[b]{2}{*}{$\begin{array}{l}\text { Per cent of change } \\
\text { from previous year }\end{array}$} & \multirow[b]{2}{*}{$\begin{array}{l}\text { Per } 100000 \text { Medicare FFS } \\
\text { enrollees }\end{array}$} & \multirow[b]{2}{*}{$\begin{array}{l}\text { Per cent of change } \\
\text { from previous year }\end{array}$} \\
\hline & & Number & Per cent & & & & & & & & \\
\hline Y2000 & 282172 & 35077 & 12.4 & 39632 & 14.0 & 34262 (86.5\%) & $5370(13.5 \%)$ & 839474 (80\%) & NA & 2118 & - \\
\hline Y2001 & 285040 & 35332 & 12.4 & 40045 & 14.0 & $34478(86.1 \%)$ & $5567(13.9 \%)$ & 989034 (78\%) & 17.8 & 2470 & 16.6 \\
\hline Y2002 & 288369 & 35605 & 12.3 & 40503 & 14.0 & 34698 (85.7\%) & $5805(14.3 \%)$ & 1172248 (74\%) & 18.5 & 2894 & 17.2 \\
\hline Y2003 & 290211 & 35952 & 12.4 & 41126 & 14.2 & $35050(85.2 \%)$ & $6078(14.8 \%)$ & 1342829 (71\%) & 14.6 & 3265 & 12.8 \\
\hline Y2004 & 292892 & 36302 & 12.4 & 41729 & 14.2 & 35328 (84.7\%) & $6402(15.3 \%)$ & $1611887(65 \%)$ & 20.0 & 3863 & 18.3 \\
\hline Y2005 & 295561 & 36752 & 12.4 & 42496 & 14.4 & 35777 (84.2\%) & $6723(15.8 \%)$ & 1747771 (65\%) & 8.4 & 4113 & 6.5 \\
\hline Y2006 & 299395 & 37264 & 12.4 & 43339 & 14.5 & 36317 (83.8\%) & $7022(16.2 \%)$ & $1844182(63 \%)$ & 5.5 & 4255 & 3.5 \\
\hline Y2007 & 301290 & 37942 & 12.6 & 44263 & 14.7 & 36966 (83.5\%) & $7297(16.5 \%)$ & 1915227 (62\%) & 3.9 & 4327 & 1.7 \\
\hline Y2008 & 304056 & 38870 & 12.8 & 45412 & 14.9 & 37896 (83.4\%) & $7516(16.6 \%)$ & 2017132 (61\%) & 5.3 & 4442 & 2.7 \\
\hline Y2009 & 307006 & 39570 & 12.9 & 45801 & 14.9 & 38177 (83.4\%) & $7624(16.6 \%)$ & 2112511 (59\%) & 4.7 & 4612 & 3.8 \\
\hline Y2010 & 308746 & 40268 & 13.0 & 46914 & 15.2 & 38991 (83.1\%) & 7923 (16.9\%) & 2205307 (57\%) & 4.4 & 4701 & 1.9 \\
\hline Y2011 & 311583 & 41370 & 13.3 & 48300 & 15.5 & 40000 (82.8\%) & $8300(17.2 \%)$ & 2289213 (58\%) & 3.8 & 4740 & 0.8 \\
\hline Y2012 & 313874 & 43144 & 13.8 & 50300 & 16.0 & 41900 (83.3\%) & $8500(16.9 \%)$ & 2304993 (58\%) & 0.7 & 4582 & -3.3 \\
\hline Y2013 & 316129 & 44704 & 14.1 & 51900 & 16.4 & 43100 (83.0\%) & $8800(17.0 \%)$ & 2259887 (58\%) & -2.0 & 4354 & -5.0 \\
\hline Y2014 & 318892 & 46179 & 14.5 & 53500 & 16.8 & $44600(83.4 \%)$ & 8900 (16.5\%) & 2255668 (57\%) & -0.2 & 4216 & -3.2 \\
\hline $\begin{array}{l}\text { Per cent } \\
\text { change from } \\
2000 \text { to } 2014\end{array}$ & 13.0 & 31.7 & 16.8 & 35.0 & 19.8 & 30.2 & 65.7 & 168.7 & - & 99.0 & \\
\hline $\begin{array}{l}\text { Geometric } \\
\text { average } \\
\text { change \%) }\end{array}$ & 0.9 & 2.0 & & 2.2 & & 1.9 & 3.7 & 7.3 & - & 5.0 & \\
\hline
\end{tabular}




\begin{tabular}{|c|c|c|c|c|c|c|c|c|c|c|c|c|c|c|c|c|}
\hline & \multicolumn{3}{|c|}{$\begin{array}{l}\text { Cervical/thoracic interlaminar } \\
\text { epidurals (CPT 62310) }\end{array}$} & \multicolumn{3}{|c|}{$\begin{array}{l}\text { Lumbar interlaminar and caudal } \\
\text { epidurals (CPT 62311) }\end{array}$} & \multicolumn{5}{|c|}{ Cervical/thoracic transforaminal epidurals } & \multicolumn{5}{|c|}{ Lumbar/sacral transforaminal epidurals } \\
\hline & Services & Rate & $\begin{array}{l}\text { Per cent of change } \\
\text { from previous year }\end{array}$ & Services & Rate & $\begin{array}{l}\text { Per cent of change } \\
\text { from previous year }\end{array}$ & $\begin{array}{l}\text { CPT } \\
64479 \\
\text { Services }\end{array}$ & $\begin{array}{l}\text { CPT } \\
64480 \\
\text { Services }\end{array}$ & $\begin{array}{l}\text { Total } \\
\text { Services }\end{array}$ & Rate & $\begin{array}{l}\text { Per cent of } \\
\text { change from } \\
\text { previous year }\end{array}$ & $\begin{array}{l}\text { CPT } \\
64483 \\
\text { Services }\end{array}$ & $\begin{array}{l}\text { CPT } \\
64484 \\
\text { Services }\end{array}$ & $\begin{array}{l}\text { Total } \\
\text { Services }\end{array}$ & Rate & $\begin{array}{l}\text { Per cent of change } \\
\text { from previous year }\end{array}$ \\
\hline 2000 & 75741 & 191 & - & 618362 & 1560 & - & 13454 & 9434 & 22888 & 58 & - & 85006 & 37477 & 122483 & 309 & - \\
\hline 2001 & 84385 & 211 & 10.3 & 702713 & 1755 & 12.5 & 14732 & 8537 & 23269 & 58 & 0.6 & 125534 & 53133 & 178667 & 446 & 44.4 \\
\hline 2002 & 99117 & 245 & 16.1 & 786919 & 1943 & 10.7 & 18583 & 10835 & 29418 & 73 & 25.0 & 177679 & 79115 & 256794 & 634 & 42.1 \\
\hline 2003 & 109783 & 267 & 9.1 & 838858 & 2040 & 5.0 & 21882 & 15769 & 37651 & 92 & 26.0 & 242491 & 114046 & 356537 & 867 & 36.7 \\
\hline 2004 & 130649 & 313 & 17.3 & 878174 & 2104 & 3.2 & 25182 & 18094 & 43276 & 104 & 13.3 & 363744 & 196044 & 559788 & 1341 & 54.7 \\
\hline 2005 & 141652 & 333 & 6.5 & 945350 & 2225 & 5.7 & 27844 & 20525 & 48369 & 114 & 9.8 & 395508 & 216892 & 612400 & 1441 & 7.4 \\
\hline 2006 & 146748 & 339 & 1.6 & 946961 & 2185 & -1.8 & 29822 & 23073 & 52895 & 122 & 7.2 & 452125 & 245453 & 697578 & 1610 & 11.7 \\
\hline 2007 & 156415 & 353 & 4.4 & 926029 & 2092 & -4.3 & 29938 & 22266 & 52204 & 118 & -3.4 & 506274 & 274305 & 780579 & 1764 & 9.6 \\
\hline 2008 & 165636 & 365 & 3.2 & 905419 & 1994 & -4.7 & 32286 & 24003 & 56289 & 124 & 5.1 & 572340 & 317448 & 889788 & 1959 & 11.1 \\
\hline 2009 & 175503 & 383 & 5.1 & 888166 & 1939 & -2.7 & 37012 & 27487 & 64499 & 141 & 13.6 & 632658 & 351685 & 984343 & 2149 & 9.7 \\
\hline 2010 & 184750 & 394 & 2.8 & 888421 & 1894 & -2.3 & 40003 & 29888 & 69891 & 149 & 5.8 & 679117 & 383128 & 1062245 & 2264 & 5.4 \\
\hline 2011 & 200134 & 414 & 5.2 & 914324 & 1893 & 0.0 & 38970 & 26628 & 65598 & 136 & -8.8 & 710638 & 398519 & 1109157 & 2296 & 1.4 \\
\hline 2012 & 213390 & 424 & 2.4 & 925179 & 1839 & -2.8 & 35945 & 21293 & 57238 & 114 & -16.2 & 718437 & 390749 & 1109186 & 2205 & -4.0 \\
\hline 2013 & 217393 & 419 & -1.3 & 901468 & 1737 & -5.6 & 34699 & 20409 & 55108 & 106 & -6.7 & 700820 & 385098 & 1085918 & 2092 & -5.1 \\
\hline 2014 & 208741 & 390 & -6.9 & 815858 & 1525 & -12.2 & 37944 & 21587 & 59531 & 111 & 4.8 & 763793 & 407745 & 1171538 & 2190 & 4.7 \\
\hline \multicolumn{17}{|c|}{ Per cent of change from 2000 to 2014} \\
\hline Change & 176 & 104 & - & 32 & -2 & - & 182 & 129 & 160 & 93 & - & 799 & 988 & 856 & 609 & - \\
\hline \multicolumn{17}{|c|}{ Geometric average annual change (\%) } \\
\hline Geometric average & 7.5 & 5.2 & - & 2.0 & -0.2 & - & 7.7 & 6.1 & 7.1 & 4.8 & - & 17.0 & 18.6 & 17.5 & 15.0 & - \\
\hline
\end{tabular}

Rate-per 100000 Medicare beneficiaries. 


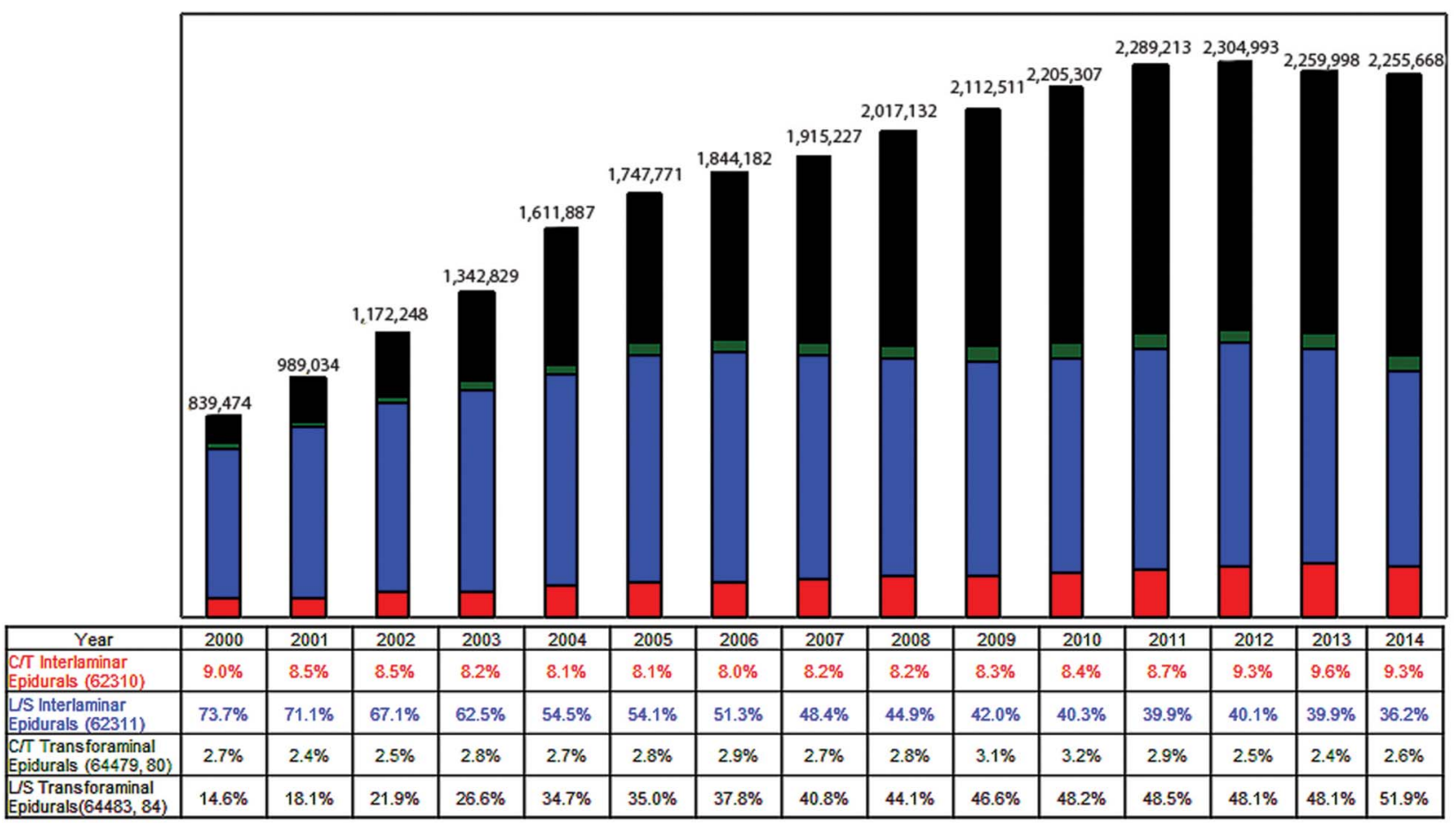

Figure 1 Frequency of usage of epidural injections by procedures from 2000 to 2014, in Medicare recipients.

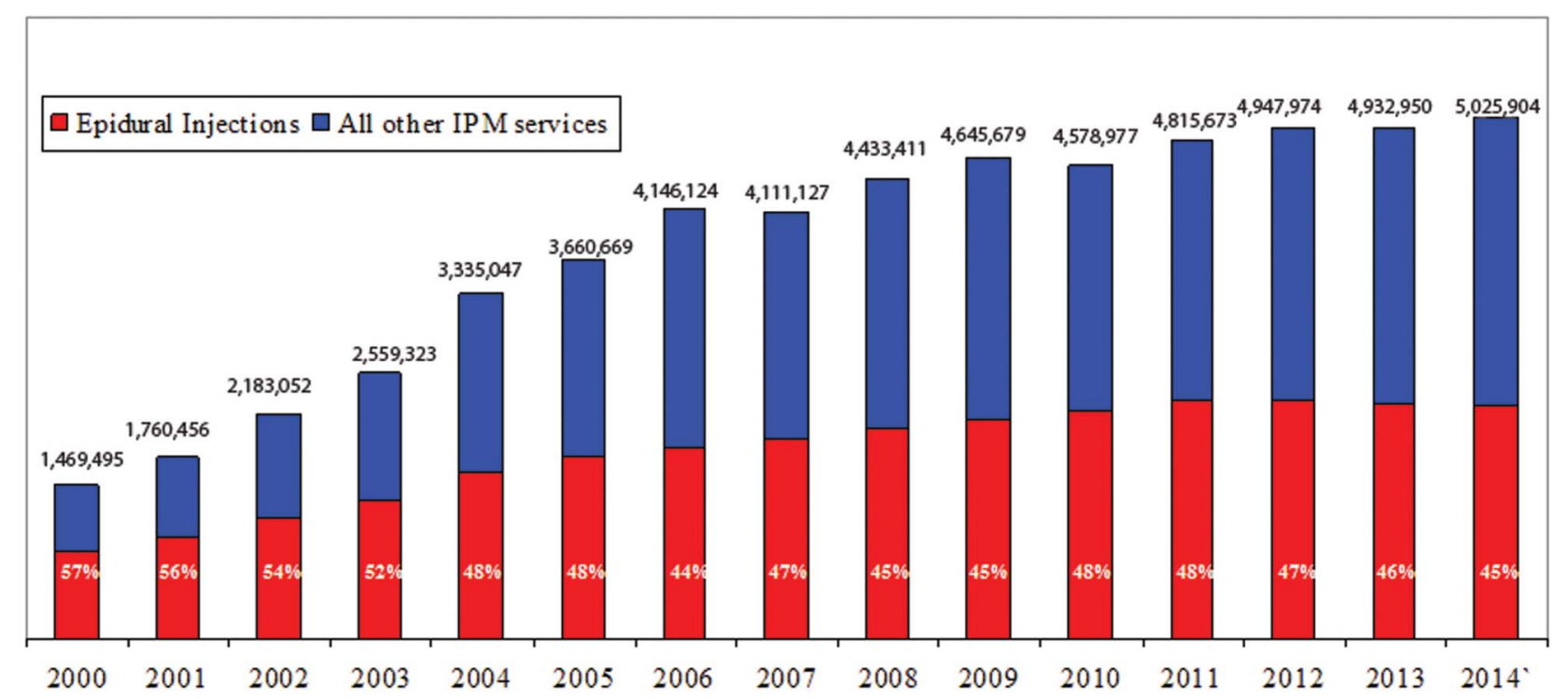

Figure 2 Frequency of usage of epidural injections and all other interventional pain management procedures from 2000 to 2014, in Medicare recipients.

However, the ratio of lumbosacral transforaminal epidural injections increased from $14.6 \%$ of all epidural injection in 2000 to $51.9 \%$ in 2014 , thus, exceeding interlaminar epidural injections.

- Site-of-service usage patterns showed a decrease in HOPDs associated with a dramatic increase in in-office procedures.

\section{DISCUSSION}

Usage of epidural injections for chronic spinal pain in the FFS Medicare population in the USA increased dramatically from 2000 to 2014. The increase for epidural injections has been shown to be $99 \%$ per 100000 Medicare beneficiaries with an annual increase of $5 \%$, compared to the increase of Medicare beneficiaries per 100000 population of $35 \%$ with an annual increase of $2.2 \%$ during the same period. The increases were predominantly noted for lumbar transforaminal epidural injections with a $609 \%$ increase per 100000 Medicare population from 2000 to 2014 with an annual increase of $15.0 \%$. The increases were modest with $93 \%$ for cervical and thoracic transforaminal epidural injections and $104 \%$ for cervical and thoracic interlaminar epidural 
injections per 100000 Medicare population. Usage of cervical/thoracic interlaminar epidural injections decreased by $6.9 \%$, from 217393 to 208 741, from 2013 to 2014 and for lumbar/sacral interlaminar epidural injections $9 \%$ from 901468 to 815858 , whereas there was an $8 \%$ increase in cervical/thoracic transforaminal epidural injections from 55108 to 59531 and an 8\% increase in lumbar/sacral transforaminal epidural injections from 1085918 to 1171538 . Dramatic increases were noted for lumbosacral transforaminal epidural injections from a baseline rate of 309 in 2000 to 2190 in 2014 for per 100000 Medicare population, an increase of $609 \%$ or an annual rate of $15 \%$. In contrast, interlaminar epidural injections in the lumbar spine, which also include caudal epidural injections, have decreased $2 \%$ with an annual decrease of $0.2 \%$ from 1560 in 2000 per 100000 Medicare population to 1525 in 2014. Consequently, only interlaminar epidural injections correlated with overall Medicare beneficiary growth, which has been shown to be $35 \%$ and growth of Medicare beneficiaries above age 65 years vs below 65 years with $30.2 \%$ vs $65.7 \%$. There was also change in site of service usage patterns with a decrease in HOPD use and a dramatic increase in in-office services. ASC share increased from $19.9 \%$ in 2002 to $27.7 \%$ in 2014 and in-office services dramatically increased from $25.8 \%$ in 2002 to $42.9 \%$ in 2014 (see online supplementary appendices 3 and 4), whereas HOPD share decreased from $54.3 \%$ to $29.4 \%$.

As shown in online supplementary appendices 2 and 3 , specialty characteristics showed that an overwhelming majority of the procedures $(89.5 \%)$ were performed by pain management specialists, which essentially remained stable over the years. Surgery was a distant second specialty with $4.5 \%$ and radiology followed with $3.8 \%$ usage. Surgical specialties performed fewer procedures when compared to 2000, whereas radiologists performed more procedures. General physicians and other providers including Certified Registered Nurse Anesthetists, nurse practitioners and Physician Assistants also provided a lesser number of epidural injections than in 2000.

The results demonstrated in this evaluation were similar to other recently performed evaluations. ${ }^{11-15}$ However, these results are noteworthy compared to some of the previous studies, which focused on different aspects rather than assessment of growth and usage. ${ }^{47-49}$ Friedly $e t a l^{47} 48$ and Abbott $e t a l^{49}$ indicate that injection therapies were provided with lack of evidence for managing chronic low back pain. Abbott et a $t^{49}$ also included analysis of a publication from the Office of Inspector General in $2010^{50}$ with multiple recommendations to curb the growth of lumbosacral transforaminal epidurals that showed a lack of significant effect or, at most, mild influence. Another paradoxical development is that transforaminal epidural injections have exceeded the total number of lumbar interlaminar and caudal epidural injections starting in 2009, which essentially reversed a long-standing trend of a high proportion of interlaminar and caudal epidural injections compared to transforaminal epidural injections, despite multiple reports of complications and resultant warnings. ${ }^{1-5}$ 11-15

Some of the limitations for our assessment include lack of inclusion of patients participating in Medicare Advantage Plans, which could lead to exclusion of $\sim 20$ $30 \%$ of the population. Further, there is also potential for coding errors and elimination of procedures which are not commonly used for spinal pain, such as continuous epidural injections and neurolytic procedures, may underestimate the number of procedures performed. However, the advantages of this study include that we have used the full Medicare data instead of an extrapolation and also all Medicare FFS population instead of using only those 65 years or older.

The increasing prevalence, disability, healthcare costs and human toll of spinal pain, the increasing usage of all modalities, specifically epidural injections-the subject of this assessment-continue to incite controversy and provide the basis of the claims that epidural injections are overused, leading to inappropriate use, abuse and fraud without evidence of efficacy, medical necessity and indications. ${ }^{12} 24-263738$ The supporters of various modalities continue to profess cautious use with demonstration of effectiveness and cost utility, claim that spinal pain continues to increase, along with its understanding, which continues to evolve over the years. ${ }^{24-36} 394051$ Thus, epidural injections in managing chronic spinal pain are justified with moderate evidence available in support of these injections in appropriately conducted randomised trials and systematic reviews. $^{12}$ 24-26 373851 However, others have provided contradictory evidence with lack of effectiveness demonstrated in high-profile assessments. ${ }^{25} 2637$ These reports have been extensively critiqued. ${ }^{24} 27-32{ }^{52-56}$ In addition to substantial differences between proponents and opponents with the majority of the government-sponsored studies in the USA showing lack of effectiveness of epidural injections in managing low back and lower extremity pain, Lewis $e t a l^{39} 40$ in two separate manuscripts funded by the National Health Services (NHS) and health technology assessment programme have presented positive results for epidural injections. In a systematic review and economic model of the clinical and cost-effectiveness of management strategies for sciatica performed for the health technology assessment, ${ }^{39}$ results were positive for demonstrating the effectiveness of epidural corticosteroid injections. They ${ }^{40}$ also showed, in a systematic review and network meta-analysis of comparative clinical effectiveness of management strategies for sciatica with review of 122 relevant studies and 21 treatment strategies, statistically significant improvement with epidural injections. In addition, network meta-analysis ${ }^{40}$ also showed superiority of epidural injections to traction, percutaneous discectomy and exercise therapy.

Overall, this assessment shows a continued increase of usage from 2000 to 2011, with subsequent decreasing patterns of usage of epidural injections. However, 
large-scale and seemingly inappropriate increases in usage are related to lumbar transforaminal epidural injections, whereas there was a net decrease of lumbar interlaminar and caudal epidural injections. Even though epidural injections have constituted smaller increases when compared to other modalities, with continued controversy and the increase of $609 \%$ in lumbosacral transforaminal epidural injections from 2000 to 2014, and associated major complications related to transforaminal epidural injections, caution must be exercised in performing these procedures, specifically transforaminal epidural injections. Thus, it is essential not only to develop appropriate evidence, but also to synthesise the evidence using up-to-date randomised controlled trials and proper methodology without confluence of bias. With such analysis of the data, there is no superiority for transforaminal epidural injections compared to interlaminar epidural injections in the lumbar or cervical spine. ${ }^{24272930325758}$

\section{CONCLUSIONS}

The use of epidural injections escalated from 2000 to 2011 with a small decline since then. However, dramatic increases were shown in usage patterns of lumbar transforaminal epidural injections despite rare complications, warnings and measures reducing the overall impact.

Acknowledgements The authors wish to thank Tom Prigge, MA, and Laurie Swick, BS, for manuscript review; and Tonie M. Hatton and Diane E. Neihoff, transcriptionists, for their assistance in the preparation of this manuscript.

Competing interests LM has provided limited consulting services to Semnur Pharmaceuticals, Incorporated, which is developing non-particulate steroids. $\mathrm{JAH}$ is a consultant for Medtronic

Provenance and peer review Not commissioned; externally peer reviewed.

Data sharing statement No additional data are available.

Open Access This is an Open Access article distributed in accordance with the Creative Commons Attribution Non Commercial (CC BY-NC 4.0) license which permits others to distribute, remix, adapt, build upon this work noncommercially, and license their derivative works on different terms, provided the original work is properly cited and the use is non-commercial. See: http:// creativecommons.org/licenses/by-nc/4.0/

\section{REFERENCES}

1. Rathmell JP, Benzon HT, Dreyfuss $P$, et al. Safeguards to prevent neurologic complications after epidural steroid injections: consensus opinions from a multidisciplinary working group and national organizations. Anesthesiology 2015;122:974-84.

2. US Food and Drug Administration. Drug Safety Communications FDA Drug Safety Communication: FDA requires label changes to warn of rare but serious neurologic problems after epidural corticosteroid injections for pain. http://www.fda.gov/downloads/ Drugs/DrugSafety/UCM394286.pdf (accessed 22 Mar 2016).

3. Food and Drug Administration. Anesthetic and Analgesic Drug Products Advisory Committee Meeting. November 24-25, 2014 Epidural steroid injections (ESI) and the risk of serious neurologic adverse reactions. http://www.fda.gov/downloads/AdvisoryCommittees/ CommitteesMeetingMaterials/Drugs/AnestheticAndAnalgesicDrug ProductsAdvisoryCommittee/UCM422692.pdf (accessed 22 Mar 2016).

4. Manchikanti L, Candido KD, Singh V, et al. Epidural steroid warning controversy still dogging FDA. Pain Physician 2014;17:E451-74.

5. Manchikanti L, Falco FJE, Benyamin RM, et al. Epidural steroid injections safety recommendations by the Multi-Society Pain
Workgroup (MPW): more regulations without evidence or clarification. Pain Physician 2014;17:E575-88.

6. Manchikanti L, Hirsch JA. Neurological complications associated with epidural steroid injections. Curr Pain Headache Rep 2015;19:482.

7. Manchikanti L, Falco FJE. Safeguards to prevent neurologic complications after epidural steroid injections: analysis of evidence and lack of applicability of controversial policies. Pain Physician 2015;18:E129-38.

8. Bogduk N, Brazenor G, Christophidis N, et al. Epidural use of steroids in the management of back pain. Report of working party on epidural use of steroids in the management of back pain. Canberra, Commonwealth of Australia: National Health and Medical Research Council, 1994:1-76.

9. Rajaee SS, Bae HW, Kanim LE, et al. Spinal fusion in the United States: analysis of trends from 1998 to 2008. Spine 2012;37:67-76.

10. Dart RC, Surratt HL, Cicero TJ, et al. Trends in opioid analgesic abuse and mortality in the United States. $N$ Engl J Med 2015;372:241-8.

11. Manchikanti L, Pampati V, Falco FJE, et al. Assessment of the growth of epidural injections in the Medicare population from 2000 to 2011. Pain Physician 2013;16:E349-64

12. Manchikanti L, Helm II S, Singh V, et al. Accountable interventional pain management: a collaboration among practitioners, patients, payers, and government. Pain Physician 2013;16:E635-70.

13. Manchikanti L, Pampati V, Falco FJE, et al. Growth of spinal interventional pain management techniques: analysis of utilization trends and Medicare expenditures 2000 to 2008. Spine 2013;38:157-68.

14. Manchikanti L, Pampati V, Falco FJE, et al. An updated assessment of utilization of interventional pain management techniques in Medicare population: 2000-2013. Pain Physician 2015;18:E115-27.

15. Manchikanti L, Pampati V, Hirsch JA. Utilization of interventional techniques in managing chronic pain in Medicare population from 2000 to 2014: an analysis of patterns of utilization. Pain Physician 2016;19:E531-46.

16. Atluri S, Sudarshan G, Manchikanti L. Assessment of the trends in medical use and misuse of opioid analgesics from 2004 to 2011. Pain Physician 2014;17:E119-28.

17. Gaskin DJ, Richard P. The economic costs of pain in the United States. J Pain 2012;13:715-24.

18. Martin BI, Turner JA, Mirza SK, et al. Trends in health care expenditures, utilization, and health status among US adults with spine problems, 1997-2006. Spine 2009;34:2077-84.

19. Murray CJ, Atkinson C, Bhalla K, et al., US Burden of Disease Collaborators. The state of US health, 1999-2010: burden of diseases, injuries, and risk factors. JAMA 2013;310:591-608.

20. Hoy D, March L, Brooks $P$, et al. The global burden of low back pain: estimates from the Global Burden of Disease 2010 study. Ann Rheum Dis 2014;73:968-74.

21. Hoy D, March L, Woolf $A$, et al. The global burden of neck pain: estimates from the global burden of disease 2010 study. Ann Rheum Dis 2014;73:1309-15.

22. Freburger JK, Holmes GM, Agans RP, et al. The rising prevalence of chronic low back pain. Arch Intern Med 2009;169:251-8.

23. Manchikanti L, Singh V, Falco FJE, et al. Epidemiology of low back pain in adults. Neuromodulation $2014 ; 17($ Suppl 2):3-10.

24. Manchikanti L, Abdi S, Atluri S, et al. An update of comprehensive evidence-based guidelines for interventional techniques in chronic spinal pain. Part II: Guidance and recommendations. Pain Physician 2013;16:S49-83.

25. Chou R, Hashimoto R, Friedly J, et al. Pain Management Injection Therapies for Low Back Pain. Technology Assessment Report ESIB0813 (prepared by the Pacific Northwest Evidence-based Practice Center under Contract No. HHSA 290-2012-00014-I). Rockville (MD): Agency for Healthcare Research and Quality; 20 March 2015

26. Pinto RZ, Maher CG, Ferreira ML, et al. Epidural corticosteroid injections in the management of sciatica: a systematic review and meta-analysis. Ann Intern Med 2012;157:865-77.

27. Manchikanti L, Benyamin RM, Falco FJ, et al. Do epidural injections provide short- and long-term relief for lumbar disc herniation? A systematic review. Clin Orthop Relat Res 2015;473:1940-56.

28. Manchikanti L, Nampiaparampil DE, Candido KD, et al. Do cervical epidural injections provide long-term relief in neck and upper extremity pain? A systematic review. Pain Physician 2015;18:39-60.

29. Manchikanti L, Nampiaparampil DE, Manchikanti KN, et al. Comparison of the efficacy of saline, local anesthetics, and steroids in epidural and facet joint injections for the management of spinal pain: a systematic review of randomized controlled trials. Surg Neurol Int 2015;6:S194-235. 
30. Manchikanti L, Kaye AD, Manchikanti KN, et al. Efficacy of epidural injections in the treatment of lumbar central spinal stenosis: a systematic review. Anesth Pain Med 2015;5:e23139.

31. Manchikanti L, Staats PS, Nampiaparampil DE, et al. What is the role of epidural injections in the treatment of lumbar discogenic pain a systematic review of comparative analysis with fusion. Korean $J$ Pain 2015;28:75-87.

32. Manchikanti L, Knezevic NN, Boswell MV, et al. Epidural injections for lumbar radiculopathy and spinal stenosis: a comparative systematic review and meta-analysis. Pain Physician 2016;19: E365-410.

33. Liu K, Liu P, Liu R, et al. Steroid for epidural injection in spinal stenosis: a systematic review and meta-analysis. Drug Des Devel Ther 2015;9:707-16.

34. Bicket $\mathrm{MC}$, Gupta $\mathrm{A}$, Brown $\mathrm{CH}$, et al. Epidural injections for spinal pain: a systematic review and meta-analysis evaluating the "control" injections in randomized controlled trials. Anesthesiology 2013;119:907-31.

35. Lee J, Gupta S, Price C, et al., British Pain Society. Low back and radicular pain: a pathway for care developed by the British Pain Society. Br J Anaesth 2013;111:112-20.

36. Macvicar J, King W, Landers MH, et al. The effectiveness of lumbar transforaminal injection of steroids: a comprehensive review with systematic analysis of the published data. Pain Med 2013;14:14-28.

37. Staal JB, de Bie RA, de Vet $\mathrm{HC}$, et al. Injection therapy for subacute and chronic low back pain: an updated Cochrane review. Spine 2009;34:49-59.

38. Chou R, Hashimoto R, Friedly J, et al. Epidural corticosteroid injections for radiculopathy and spinal stenosis: a systematic review and meta-analysis. Ann Intern Med 2015;163:373-81.

39. Lewis RA, Williams N, Matar HE, et al. The clinical effectiveness and cost-effectiveness of management strategies for sciatica: systematic review and economic model. Health Technol Assess 2011;15:1-578.

40. Lewis RA, Williams NH, Sutton AJ, et al. Comparative clinical effectiveness of management strategies for sciatica: systematic review and network meta-analyses. Spine J 2015;15:1461-77.

41. Racoosin JA, Seymour SM, Cascio L, et al. Serious neurologic events after epidural glucocorticoid injection-the FDA's risk assessment. N Engl J Med 2015;373:2299-301.

42. Kainer MA, Reagan DR, Nguyen DB, et al., Tennessee Fungal Meningitis Investigation Team. Fungal infections associated with contaminated methylprednisolone in Tennessee. N Engl J Med 2012;367:2194-203.

43. Manchikanti L, Malla Y, Wargo BW, et al. A prospective evaluation of complications of 10,000 fluoroscopically directed epidural injections. Pain Physician 2012;15:131-40.

44. Atluri S, Glaser SE, Shah RV, et al. Needle position analysis in cases of paralysis from transforaminal epidurals: Consider alternative approaches to traditional technique. Pain Physician 2013;16:321-34.
45. Specialty utilization data files from Centers for Medicare and Medicaid Services. http://www.cms.hhs.gov/ (accessed 22 Mar 2016).

46. Vandenbroucke JP, Von Elm E, Altman DG, et al., Iniciativa STROBE. Strengthening the reporting of observational studies in epidemiology (STROBE): Explanation and elaboration. Gac Sanit 2009;23:158.

47. Friedly J, Chan L, Deyo R. Increases in lumbosacral injections in the Medicare population: 1994 to 2001. Spine 2007;32:1754-60.

48. Friedly J, Chan L, Deyo R. Geographic variation in epidural steroid injection use in Medicare patients. J Bone Joint Surg Am 2008;90:1730-7.

49. Abbott ZI, Nair KV, Allen RR, et al. Utilization characteristics of spinal interventions. Spine J 2012;12:35-43.

50. US Department of Health and Human Services. Office of Inspector General (OIG). Inappropriate Medicare Payments for Transforaminal Epidural Injection Services (OEl-05-09-00030). August 2010. http:// oig.hhs.gov/oei/reports/oei-05-09-00030.pdf (accessed 22 Mar 2016).

51. Manchikanti L, Falco FJE, Pampati V, et al. Cost utility analysis of caudal epidural injections in the treatment of lumbar disc herniation, axial or discogenic low back pain, central spinal stenosis, and post lumbar surgery syndrome. Pain Physician 2013;16:E129-43.

52. Manchikanti L, Benyamin RM, Falco FJE, et al. Guidelines warfare over interventional techniques: is there a lack of discourse or straw man? Pain Physician 2012;15:E1-26.

53. Manchikanti L, Kaye AD, Hirsch JA. Comment RE: Chou R, Hashimoto R, Friedly J, et al. RE: Epidural corticosteroid injections for radiculopathy and spinal stenosis: a systematic review and meta-analysis. Ann Intern Med 2015;163:373-81. Ann Intern Med 2016;164:633.

54. Manchikanti L, Boswell MV. Appropriate design and methodologic quality assessment, clinically relevant outcomes are essential to determine the role of epidural corticosteroid injections. Commentary RE: Chou R, Hashimoto R, Friedly J, et al. Epidural corticosteroid injections for radiculopathy and spinal stenosis: a systematic review and meta-analysis. Ann Intern Med 2015;163:373-81. Evid Based Med; 17 February 2016.

55. Eden J, Levit L, Berg A, et al., eds. Committee on Standards for Systematic Reviews of Comparative Effectiveness Research; Institute of Medicine. Finding what works in health care. Standards for systematic reviews. Washington (DC): The National Academies Press, 2011.

56. Cappola AR, FitzGerald GA. Confluence, not conflict of interest: name change necessary. JAMA 2015;314:1791-2.

57. Chang Chien GC, Knezevic NN, McCormick Z, et al. Transforaminal versus interlaminar approaches to epidural steroid injections: a systematic review of comparative studies for lumbosacral radicular pain. Pain Physician 2014;17:E509-24.

58. Manchikanti L, Singh V, Pampati V, et al. Comparison of the efficacy of caudal, interlaminar, and transforaminal epidural injections in managing lumbar disc herniation: Is one method superior to the other? Korean J Pain 2015;28:11-21. 